\title{
Simulating the impact of climate change on maize production in Ethiopia, East Africa
}

\author{
Kidist Abera ${ }^{1,2^{*}}$, Olivier Crespo ${ }^{1}$, Jemal Seid ${ }^{2}$ and Fasil Mequanent ${ }^{2}$
}

\begin{abstract}
Background: Climate change is expected to significantly impact agricultural production across Africa. While a number of studies assessed this impact in semi-arid southern Africa, or tropical West Africa, only a limited number took interest in the mountainous and climatically varying Ethiopia of eastern Africa. This study assesses the impact of climate change on maize production in three representative sites of maize growing areas in Ethiopia. The assessment relies on the DSSAT crop model simulation of maize under current climate and future projections (19 Global Climate Models and 2 Representative Concentration Pathways). The period 1980-2010 was used to represent the baseline climate, while future climate projections cover three periods; near term (2010-2039), mid-century (2040-2069) and end-of-century (2070-2099). Climate, soil and crop management data were collected for the study sites representing the maize growing areas in the country.

Results: Results show that maize yields will decrease by up to 43 and $24 \%$ by the end of the century at Bako and Melkassa stations, respectively, while simulated maize yield in Hawassa show an increase of 51\%. On the one hand, rainfall variability and rising temperatures are determining factors explaining yield decrease in Bako and Melkassa, while projected rainfall increase in Hawassa explain simulated yield increases.

Conclusion: The terrain and climate high variability of Ethiopia is emphasizing the extremely different responses of current agricultural systems to climate change. Though adaptation approached can address some negative impacts, and in some case can take advantage of changes, this study reveals that dedicated local knowledge is necessary for national and regional decision makers to respond with local relevance to a global exposure, in order to face food security challenges.
\end{abstract}

Keywords: Climate change, Maize, Crop model, Local adaptation, East Africa

\section{Background}

Developing countries, including African countries, are vulnerable to climate change due to increase of stresses such as human population, water scarcity, land degradation and food insecurity (IPCC 2012; World Bank 2010). Climate change can affect the sustainability of agriculture systems and will therefore challenge vulnerable people who depend on local food production (Wheeler and von Braun 2013; Müller et al. 2011; Boko et al. 2007). Severity will be accrued in arid and semi-arid areas of Africa where water resources are very sensitive to climate

\footnotetext{
*Correspondence: kidistabera03@gmail.com

2 Ethiopian Institute of Agricultural Research, P.O. Box 2003, Addis Ababa, Ethiopia

Full list of author information is available at the end of the article
}

variability, particularly temperature and rainfall. Moreover, the majority of small scale agricultural systems, as commonly found in developing African countries, are rain-fed, hence directly affected by unpredictable temperature and rainfall variations, resulting in yield reduction or crop failure (Kurukulasuriya et al. 2006).

Poor agrarian economies such as Ethiopia are considered among the most at risk from the impact of climate change/variability on agricultural productivity, with direct consequences on national food security. The country's economy is highly dependent on rain-fed agriculture with only $5 \%$ of the agricultural land being under irrigation (AGRA 2014). Agricultural production or crop failure due to shortage of water during the growing season 
is a threat for the rain-fed cropping systems in semi-arid Ethiopia (Kassie et al. 2013).

Previous studies have shown that climate variability and associated droughts have been major causes of food insecurity and famine in Ethiopia (Tesfaye et al. 2017; Alemayehu and Bewket 2016; Bewket 2009). For instance, the worst disaster in Ethiopia has experienced in 1983/84 failure of the main rainfall season, and resulted in reduction of the agricultural outputs by $21 \%$, and GDP by 9.7\% (World Bank 2006). FAO (2016) also reported that because of El Niño caused drought in 2015/2016, the average number of food insecure people in Ethiopia was of more than 10 million.

Agricultural output in Ethiopia is highly dependent on erratic, unevenly distributed and difficult to forecast rainfall intensity and distribution (Tefera 2012; Bewket 2009). Ethiopian economy and especially its agricultural sector are expected to be significantly affected by future climatic conditions. Eshetu et al. (2014) suggested the GDP could decrease by $0.5-2.5 \%$ per year in the near future. Rainfall variability alone could account for 2 billion USD loss in the agricultural sector. Ethiopia readiness ranks 151 (GAIN Index 2013), as an indicator of its capacity to cope with the impact of climate change (poor on adaptation). There are high levels of confidence in forecasting ongoing temperature and mean rainfall increase over the country, however, climate change impacts depend on the extent of emission scenarios and climatic models. For instance, there are several studies that showed Ethiopia would experience further warming by the years $2020 \mathrm{~s}$ and 2050s in all seasons (Hadgu et al. 2015; Jury and Funk 2013; Ayalew et al. 2012; Conway and Schipper 2011). Annual rainfall is also expected to increase, but there is much uncertainty on the spatial and temporal patterns (Conway and Schipper 2011; Bewket and Conway 2007). Consequently climate change is expected to significantly impact crop production (Muluneh et al. 2015; Deressa and Hassan 2009), thus bearing profound effects on the livelihood of local communities (Hadgu et al. 2015; Kassie et al. 2013).

Maize is the most important cereal cultivated in Ethiopia as it ranks second after teff in area coverage, first in total national production and yield per hectare (CSA 2015). The national maize yield average is of $2.95 \mathrm{t} / \mathrm{ha}$ (CSA 2012). This is far below the world's average which is about $5.66 \mathrm{t} / \mathrm{ha}$ (USDA 2016). This low productivity is attributed to several factors amongst which frequent droughts, declining soil fertility, poor agronomic practices, limited use of inputs, insufficient access to technology, lack of credit facilities, poor seed quality, incidence of diseases, pests and weeds (Taffesse et al. 2011; Erkossa et al. 2007). According to Muluneh et al. (2015), maize yields will reduce as a result of climate change for the semi-arid areas of Ethiopia by 2080 s by up to $46 \%$, but could result an increase by up to $59 \%$ result in subhumid/humid areas. There is a great variety of possible adaptive responses available to deal with climate change/ variability. These include technological options such as use of fertilizers, altering planting dates and supplemental irrigation (Bryan et al. 2009). The main challenge, however, continues to be identification of the most effective combination of possible strategies and technologies in a particular context (Burney et al. 2014).

Different studies conducted on climate change impacts over the past decades in Ethiopia have reported mixed relationships between climate change and crop production. Alemayehu and Bewket (2016), Bewket (2009) and Lemi (2005) reported that the existence of significant correlations between climate change and crop production, while Admassu (2004) identified no significant correlations between total annual, main rainy season (Kiremt) and small rainy season (Belg) rainfall, and production of those crops (barley, maize, sorghum, teff and wheat) in most parts of the country. In light of these contradictory views, it is necessary to further quantify the impact of climate change on crop production at the local level.

The previous assessments of climate change impacts on crop production in Ethiopia were either at the national (Deressa and Hassan 2009; Admassu 2004) or larger scale such as the East African regional levels (Bryan et al. 2009; Thornton et al. 2009). There are only a few studies at subnational levels within Ethiopia exist (e.g., Alemayehu and Bewket 2016; Muluneh et al. 2015). It is necessary understanding the impact of climate change on maize yields at local scales when considering for planning and designing appropriate adaptation strategies. To the best of our knowledge, very few studies have examined the impact of climate change on maize yield at the local scale. Therefore, this study attempted to close this gap by assessing how monthly temperature and rainfall is likely to change in the future, establish how these changes affect maize production and portray how adaptation strategies can enhance future maize production over three distinct maize production areas of Ethiopia viz., Bako, Melkassa and Hawassa.

\section{Methods}

\section{Description of the study area}

The study was carried out at three locations in central Ethiopia, extending from $37.9^{\circ}$ to $38.3^{\circ}$ East and from $17.4^{\circ}$ to $9.6^{\circ}$ North (Fig. 1). Elevation ranges from $1550 \mathrm{~m}$ a.s.l near Melkassa station in Adama district in the east, to $2916 \mathrm{~m}$ a.s.l near Bako station in Bako Tibe district in the north. The studied area has a wide range of agroecological zones (AEZ), from humid to sub-humid in the highlands, to semi-arid in the southern parts (Muluneh 


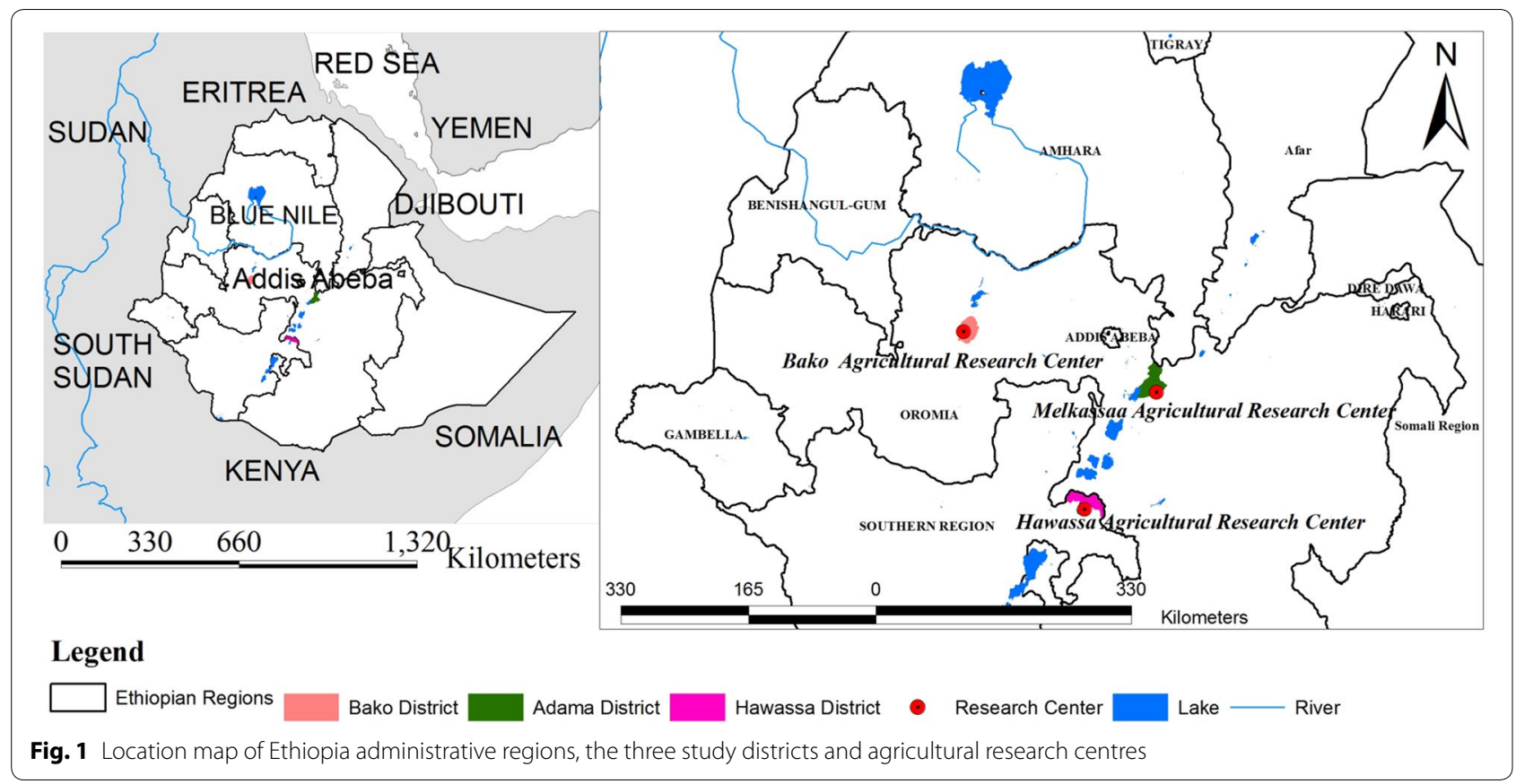

et al. 2015). Field studies were conducted in three representative sites of these maize growing areas in Ethiopia. Bako represents a highland sub-humid maize production zone, Melkassa represents a lowland semi-arid maize production zone, and Hawassa represents an intermediary sub-moist production zone. Crop production, mainly rain-fed cereal-based production systems and modest livestock rearing are the mainstays of livelihoods for households in the area. The major crops are cereals, mainly teff (Eragrostis tef), maize (Zea mays), and wheat (Triticum aestivum). In this study, the Bako Hybrid 540 (BH540) maize cultivar was used for both Bako and Hawassa stations, and the Melkassa I maize cultivar was used for Melkassa station. Maize is a long-cycle crop which is planted during the small rainy season (Belg) between March and April, and harvested between September and December.

\section{Climate characteristics}

Bako, Melkassa and Hawassa stations are characterized by a bimodal rainy season with short rains (small rainy season) in March and April, and a main rainy season from June to September (Table 1). At Bako station over 1980-2010, the mean annual rainfall was $1267.9 \mathrm{~mm}$ and the mean annual maximum and minimum temperatures were 29.9 and $13.3{ }^{\circ} \mathrm{C}$, respectively. The mean annual rainfall was also $964.7 \mathrm{~mm}$ and the mean maximum and minimum temperatures were 26.6 and $6.8{ }^{\circ} \mathrm{C}$, respectively, at Hawassa station. Melkassa station showed $807 \mathrm{~mm}$ for mean annual rainfall and, 26.6 and $14.7{ }^{\circ} \mathrm{C}$ for mean annual maximum and minimum temperatures, respectively. Over the main growing season only (JuneSeptember), the mean annual rainfall were 874.2, 281.3 and $457.4 \mathrm{~mm}$ at Bako, Melkassa and Hawassa stations, respectively. The main growing season rainfall (Kiremt) is a result of convergence in low-pressure systems associated with the Inter Tropical Convergence Zone, and small rains (Belg) rainfall is caused by humid easterly and

Table 1 Climate characteristics (1980-2010) for the three study areas (Bako, Melkassa and Hawassa stations)

\begin{tabular}{|c|c|c|c|c|c|c|c|}
\hline Station & Latitude & Longitude & Elevation (m a.s.l) & $\begin{array}{l}\text { Mean annual rain- } \\
\text { fall }(\mathrm{mm})\end{array}$ & $\begin{array}{l}\text { Mean annual rainfall } \\
(\mathrm{mm}) \text { for main grow- } \\
\text { ing season (June- } \\
\text { September) }\end{array}$ & $\begin{array}{l}\text { Mean annual maxi- } \\
\text { mum temperatures } \\
\left({ }^{\circ} \mathrm{C}\right)\end{array}$ & $\begin{array}{l}\text { Mean annual mini- } \\
\text { mum temperatures } \\
\left({ }^{\circ} \mathrm{C}\right)\end{array}$ \\
\hline Bako & $9.6^{\circ}$ & $37.9^{\circ}$ & 1680 & 1267.9 & 874.2 & 29.9 & 13.3 \\
\hline Melkassa & $8.24^{\circ}$ & $39.19^{\circ}$ & 1550 & 807 & 281.27 & 26.6 & 14.7 \\
\hline Hawassa & $7.05^{\circ}$ & $38.29^{\circ}$ & 1750 & 964.7 & 457.4 & 26.6 & 6.8 \\
\hline
\end{tabular}


south-easterly winds from the Indian Ocean (NMA 2007; Seleshi and Zanke 2004).

\section{Soil properties}

Reddish brown Nitosol, deep grey Fluvisols and Vitric Andosols are the dominant soils at Bako, Melkassa and Hawassa stations, respectively. Soil parameters such as soil lower limit (SLL), drained upper limit (DUL), and water content at saturation (SAT) were obtained from the respective research centres. Soil properties are described by layers in Table 2 .

\section{Baseline data and crop simulation model Baseline climatic data}

The baseline climates are made of daily rainfall, maximum and minimum temperatures, and daily sunshine hours for the period 1980-2010. Daily data was obtained from the Ethiopian National Meteorological Agency (NMA) and Ethiopian Institute of Agricultural Research (EIAR) archives for the three study sites. The gaps in the daily historical records over 1980-2010 were filled with a monthly bias-corrected version of the closest grid point of the AgMERRA data set, following the Agricultural Model Intercomparison and Improvement Project (AgMIP) protocoles (AgMIP 2013a, b). AgMIP is a worldwide cooperative effort linking climate, crop and socio-economic modelling to produce improved modelling capacity and better local to regional to global integrated assessment of climate change impacts on the agricultural sector (Rosenzweig et al. 2013).

\section{Simulating maize yield}

The Decision Support System for Agro-technology Transfer (DSSAT) model was used to simulate potential crop yields in response to baseline and future climates. The DSSAT suit is a software application package that encompasses over 28 crop simulation models (Hoogenboom et al. 2012). The DSSAT model is derived from the CERES and CROPSIM, and also many studies conducted by DSSAT models (Jones and Thornton 2003; Soltani and Hoogenboom 2003). It simulates the eco-physiological processes of plant growth, and commonly used to analyse yield response to future climate, relying on the best available description of soil, weather and agronomic managements (Andrew et al. 2007). The DSSAT model requires field level input data including daily weather, soil physical and chemical characteristics, crop variety parameters, and details of the crop management (Hoogenboom et al. 2012; Jones and Thornton 2003). In this study, the CERES-Maize models (Jones and Thornton 2003), which are embedded within the DSSAT version 4.5 (Hoogenboom et al. 2009), were used to simulate the phenology and yield of maize, in response to climate and management factors.

Crop model calibration The modelled soils were calibrated as described above in Table 2. The crop managements and crop variety were collected from the three respective research centres and further informed with scientific published secondary sources (Araya et al. 2015; Kassie et al. 2014). The Bako Hybrid 540 (BH540) variety was used for both Bako and Hawassa stations, and the Melkassa I variety for Melkassa station only (see Table 3). BH540 is a long maturing variety and extensively grown

Table 2 Soil properties of the study areas used for the DSSAT model. Source: Kassie et al. (2014), Araya et al. (2015)

\begin{tabular}{|c|c|c|c|c|c|c|}
\hline Site & Depth (cm) & SLL & DUL & SAT & Clay (\%) & Silt (\%) \\
\hline \multirow[t]{5}{*}{ Bako } & $5-25$ & 0.245 & 0.344 & 0.392 & 54 & 18 \\
\hline & $35-50$ & 0.26 & 0.321 & 0.39 & 54 & 12 \\
\hline & $65-80$ & 0.26 & 0.321 & 0.395 & 63 & 12 \\
\hline & 99 & 0.26 & 0.321 & 0.408 & 63 & 12 \\
\hline & 122 & 0.26 & 0.321 & 0.41 & 63 & 12 \\
\hline \multirow[t]{7}{*}{ Melkassa } & $0-10$ & 0.114 & 0.24 & 0.541 & 24 & 36 \\
\hline & $10-30$ & 0.15 & 0.29 & 0.457 & 30 & 42 \\
\hline & $30-60$ & 0.16 & 0.3 & 0.457 & 36 & 38 \\
\hline & 90 & 0.18 & 0.33 & 0.457 & 38 & 40 \\
\hline & 120 & 0.21 & 0.33 & 0.457 & 36 & 44 \\
\hline & 150 & 0.17 & 0.33 & 0.457 & 32 & 44 \\
\hline & 180 & 0.17 & 0.37 & 0.457 & 32 & 40 \\
\hline \multirow[t]{3}{*}{ Hawassa } & $0-13$ & 0.11 & 0.26 & 0.52 & 2.2 & 31.3 \\
\hline & $13-46$ & 0.09 & 0.24 & 0.52 & 0.4 & 33.2 \\
\hline & $46-130$ & 0.05 & 0.12 & 0.43 & 0.8 & 12.2 \\
\hline
\end{tabular}


Table 3 Genetic coefficients for BH540 and Melkassa I maize cultivars (Kassie et al. 2014)

\begin{tabular}{|c|c|c|c|}
\hline Code & Description & BH540 & Melkassa I \\
\hline P1 & Thermal time from emergence to end of the juvenile phase (degree days) & 220.1 & 101.5 \\
\hline P2 & Development delay for each hour increase in photoperiod above a maximum development rate (days) & 0.86 & 0.75 \\
\hline P5 & Thermal time from silking to physiological maturity (degree days) & 840.1 & 685 \\
\hline G2 & Maximum possible number of kernels per plant & 266.2 & 375 \\
\hline G3 & Kernel optimum filling rate during the linear grain filling stage (mg/day) & 10.65 & 11.65 \\
\hline PHINT & Phylochron interval: thermal time between successive leaf tip appearances (degree days) & 38.9 & 40 \\
\hline
\end{tabular}

by the farmers around Bako and Hawassa stations whereas Melkassa I is an early maturing variety and widely used by the farmers around Melkassa station (MOARD 2009; Alemu et al. 2008). The planting window ranges from 20 May to 10 June for Bako, from 17 to 30 May for Hawassa and from 10 to 20 June for Melkassa. The recommended rate of fertilizer for $\mathrm{BH} 540$ is $100 \mathrm{~kg} / \mathrm{ha}$ urea and $100 \mathrm{~kg} /$ ha di-ammonium phosphate (DAP) for Bako and Hawassa stations. For Melkassa I the recommended rate is $50 \mathrm{~kg} / \mathrm{ha}$ urea and $100 \mathrm{~kg} / \mathrm{ha}$ DAP. Row spacing is $75 \mathrm{~cm}$ for both BH540 and Melkassa I varieties and planting density is 5.3 and 6.6 plants $/ \mathrm{m}^{2}$ for BH540 and Melkassa I, respectively (Worku et al. 2012). The genetic coefficients described in Table 3 were used to calibrated modelled maize varieties (adapted from Kassie et al. 2014).

Crop model validation The comparison of simulated with observed yields allows the assessment of the model capacity to represent local crop systems. The response of the model can be evaluated using different statistical indicators such as standard errors, root mean square, index of agreement, correlation coefficient, slope and intercept of regression of observed versus predicted variables (Mourice et al. 2014; Yang et al. 2014; Jones and Thornton 2003). Here we used the root mean square error (RMSE) to evaluate our calibration, it is the difference between the observed and simulated yield as shown in Eq. 1:

$$
\operatorname{RMSE}=\frac{\sqrt{\sum\left(Y_{i}-X_{i}\right)^{2}}}{n}
$$

where $Y_{i}$ and $X_{i}$ are the simulated and observed values respectively and $n$ is the number of observations. Small values of RMSE considered as indicators for good performance of the DSSAT model.

The second criterion was the determination of index of agreement or d-statistic. It is used to measure the degree of the model prediction error, and the following Eq. 2 was used:

$$
\mathrm{d}=1-\frac{\sum\left(Y_{i}-X_{i}\right)^{2}}{\sum\left(\left|Y_{i}-X_{m}\right|+\left|X_{i}-Y_{m}\right|\right)^{2}},
$$

where $Y_{i}$, and $Y_{m}$ are simulated and mean of the simulated yield respectively. Similarly, $\mathrm{X}_{\mathrm{i}}$ and $\mathrm{X}_{\mathrm{m}}$ are observed yield and mean of observed yield, and $n$ is the number of observations. Small values of $d$ is considered as good performance of the DSSAT model (Yang et al. 2014).

The third criterion was determining the correlation coefficient (r) value. It is used to evaluate the linear relationship between the observed and modelled amounts with a value of 1.0. Thus, $r$ tests the "goodness of fit" of the linear model, $r=1$ indicates a perfect fit of the model and $r=0$ indicates that there is no linear relation.

\section{Future maize simulation \\ Future climate}

The present analysis is based on multi-downscaled products from CMIP5 dataset, 19 Global Climate Models (GCMs) which able to better reproduce present day climate as compared to observations and causal mechanisms that can provide plausible future projections in various climate changes impact studies over the region (Bhattacharjeea and Zaitchik 2015; Jury 2015; Brands et al. 2013), were selected for future climate change projections under a medium stabilization scenarios (RCP4.5) and a very high baseline emission scenarios (RCP8.5) (Taylor et al. 2012).

Future climate scenarios were generated by perturbing the daily baseline (1980-2010) with a delta factor method (Diaz-Nieto and Wilby 2005). The delta factor method is an ordinary bias correction method, which is often used to reduce the bias between the GCMs outputs and observations (Fowler et al. 2007). The main goal of this method is to modify the daily time series of the variables (i.e. precipitation, maximum and minimum temperatures) in the future years by adding monthly mean changes of GCM outputs. 19 deltas are computed as the changes from 19 Global Climate Models (GCMs) control to future projections, then monthly applied on baseline climate to produce 19 future daily sets (Trzaska and Schnarr 2014; AgMIP 2013c). The deltas were computed for two CMIP5 Representative Concentration Pathways (RCPs), i.e. RCP4.5 and RCP8.5, for three time periods; 
near term (2010-2039), mid-century (2040-2069) and end-of-century (2070-2099). For temperature, the same delta was applied to minimum and maximum temperatures. Changes in temperature and rainfall for the 2020s, 2050s, and 2080s relative to the current baseline period (1980-2010) have then been estimated based on outputs from the GCMs and the observed climate data of the three study sites. The adjusted formula for modified daily precipitation is expressed in Eq. 3, and the modified daily temperature (maximum and minimum temperatures) is expressed in Eq. 4.

$P_{\text {adj.fur }, d}=P_{o b s, d} \times \sum_{i=1}^{k} p_{i}\left(\bar{P}_{G C M . f u r, m} / \bar{P}_{G C M . r e f . m}\right)$

where $P_{\text {adj.fur,d }}$ is the adjusted daily rainfall for the future years, $P_{o b s, d}$ is the observed daily rainfall for the base years, $\bar{P}_{G C M . f u r, m}$ is the monthly mean rainfall of the GCM outputs for the future years, $\bar{P}_{G C M . r e f . m}$ is the monthly mean rainfall of the GCM outputs for the base years, $p_{i}$ is the weight of each grid cell, and $\mathrm{k}$ is the number of the grid cells.

Whereas, the adjusted daily temperature $T_{a d j . f u r, d}$ is given by:

$T_{a d j ; f u r, d}=T_{o b s, d} \times \sum_{i=1}^{k} p_{i}\left(\bar{T}_{G C M . f u r, m}-\bar{T}_{G C M . r e f . m}\right)$

where $T_{a d j}$ fur,d is the adjusted daily temperature (maximum and minimum temperatures) for the future years, $T_{o b s, d}$ is the observed daily temperature for the base years, $\bar{T}_{G C M . f u r, m}$ is the monthly mean temperature of the GCM outputs for the future years, $\bar{T}_{G C M . r e f . m}$ is the monthly mean temperature of the GCM outputs for the base years, $p_{i}$ is the weight of each grid cell, and $\mathrm{k}$ is the number of the grid cells.

\section{Future crop management}

The future yields were simulated with a set of early, midseason and late planting dates. Early plantings were set to 5 May in Bako, 15 June and 17 May in Melkassa and Hawassa, respectively. Mid-season plantings were set to 15 May, 25 June and 27 May in Bako, Melkassa and Hawassa, respectively. Late plantings were set to 25 May, 5 July and 7 June in Bako, Melkassa and Hawassa, respectively. The future fertilizer applications include (1) no urea fertilizer, (2) half- and (3) full-historical urea recommended rates. This translates into (1) $0 \mathrm{~kg} / \mathrm{ha},(2) 50 \mathrm{~kg} /$ ha and (3) $100 \mathrm{~kg} / \mathrm{ha}$ urea with $100 \mathrm{~kg} / \mathrm{ha}$ DAP for Bako and Hawassa, and (1) $0 \mathrm{~kg} / \mathrm{ha}$, (2) $25 \mathrm{~kg} / \mathrm{ha}$ and (3) $50 \mathrm{~kg} /$ ha urea with $100 \mathrm{~kg} / \mathrm{ha}$ DAP for Melkassa stations. Urea application follows current recommendation, i.e. half the total amount at sowing, and half at silking at all sites. We simulated all combinations of planting dates and fertilizer rates.

\section{Yield changes under future climate}

The DSSAT model was used to simulate maize yields under future climate with the combination of planting and fertilizer rates described above. Crop models come with limitations due to the partial representation of crop systems (e.g., no pests and diseases are modelled). Hence we have not presented or discussed the absolute yields simulated, but rather focus on the percentage of yield change from baseline simulated to future simulated yields. The changes organized to present the various simulations resulting from 2 RCPs, 19 GCMs and three future time periods, compared to a single baseline.

\section{Results and discussion}

Future climate and consequent yields changes Projected change in temperature

Results from the GCM ensemble outputs under the two RCPs during future periods (2020s, 2050s and 2080s) for the three stations (Bako, Melkassa and Hawassa) revealed increasing future temperature, compared with the baseline (1980-2010) (Figs. 2, 3). The boxplots cover the range of 19 GCMs monthly temperature changes on the $\mathrm{y}$-axis, per station ( $\mathrm{x}$-axis) and per future time periods (boxplot colors). The same plot is reproduced for the two CMIP5 Representative Concentration Pathways, RCP4.5 (left) and RCP8.5 (right).

We clearly observe that the monthly mean maximum and minimum temperatures increase for all GCMs and both RCPs (see Figs. 2, 3). The maximum temperatures increase gradually in time from under $+1{ }^{\circ} \mathrm{C}$ in the nearterm period, up to $+2{ }^{\circ} \mathrm{C}$ by the end of the century under RCP4.5. Under RCP8.5, the highest maximum temperatures change is projected from under $+1{ }^{\circ} \mathrm{C}$ in the near-term period up to $3.5^{\circ} \mathrm{C}$ by the end of the century. Minimum temperatures increase is even larger. They rise from under $+1{ }^{\circ} \mathrm{C}$ in the near-term up to $+2.5{ }^{\circ} \mathrm{C}$ under RCP4.5. Under RCP8.5 increase start above $+1{ }^{\circ} \mathrm{C}$ in the near-term period up to $+4.5^{\circ} \mathrm{C}$ by the end of the century. Though the presented temperature changes vary spatially (over the three stations) and across the 19 GCMs, projections show a clear and consistent continuous increase of minimum and maximum temperatures at all locations. This agrees with previous reports that indicated future warming of the air in the different parts of Ethiopia (Hadgu et al. 2015; Ayalew et al. 2012; Conway and Schipper 2011; Setegn et al. 2011; Yimer et al. 2009). NMA (2007) was also reported an increase in mean annual temperature by $0.2{ }^{\circ} \mathrm{C}$ per decade over the country between 1960 and 2006 period. 

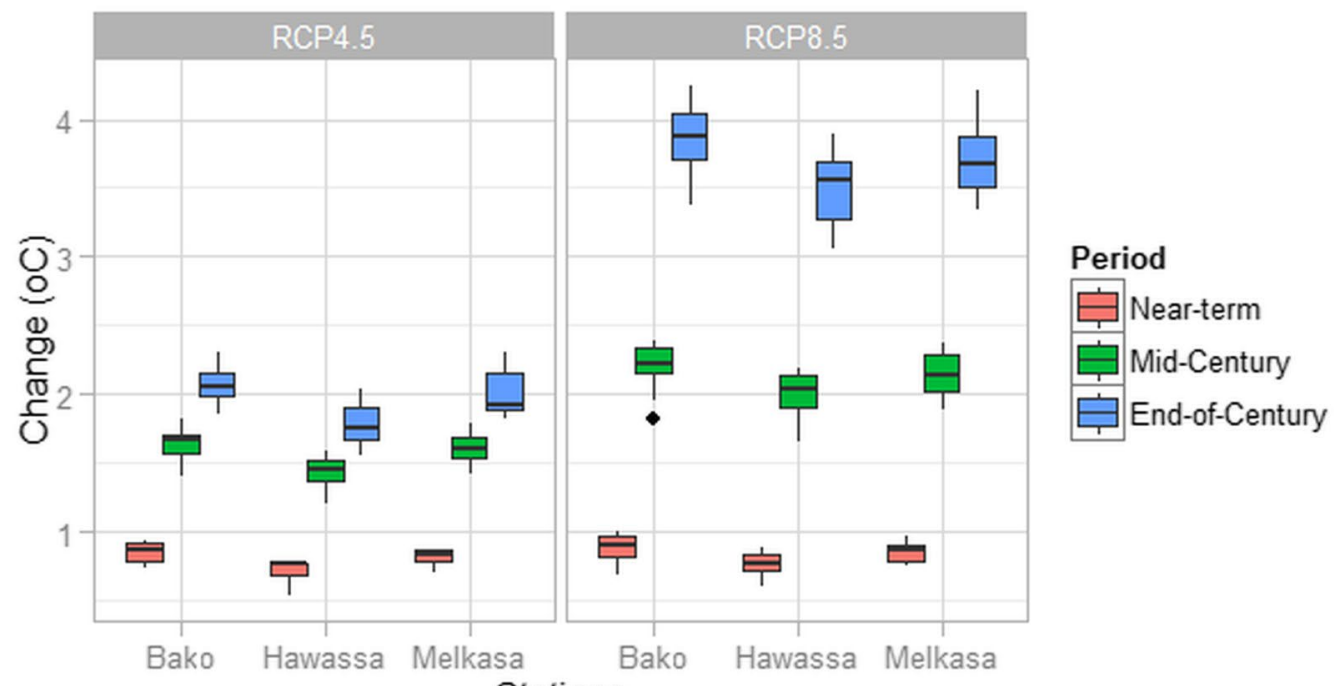

Stations

Fig. 2 Projected changes in monthly maximum temperatures for RCP4.5 (left) and RCP8.5 (right) for near term, mid-century and end of century future periods

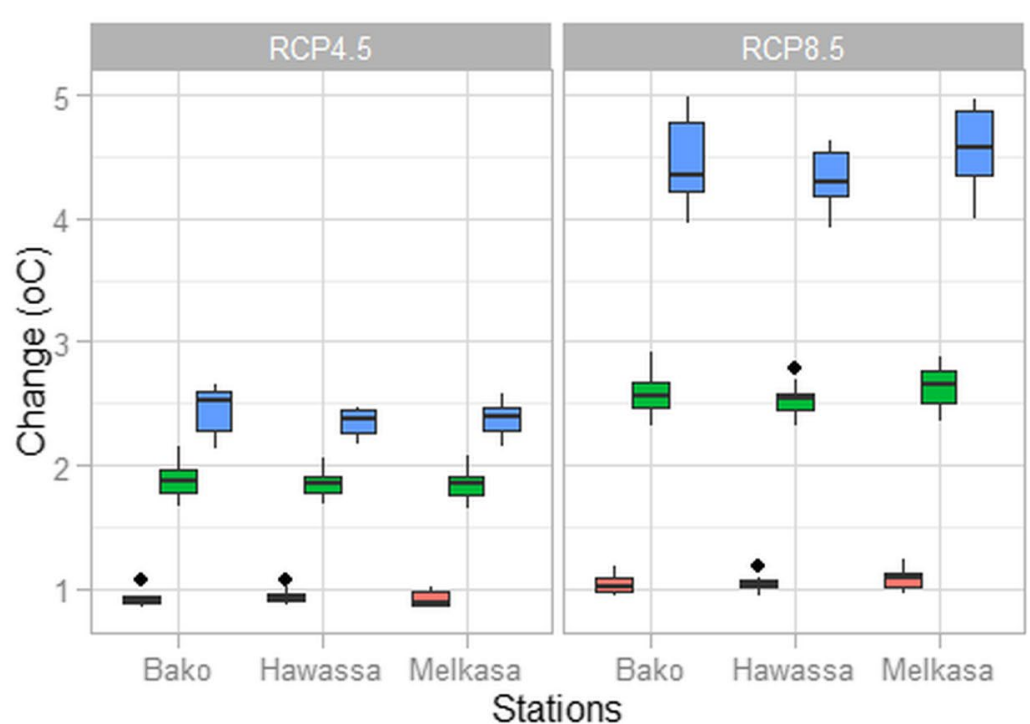

Period

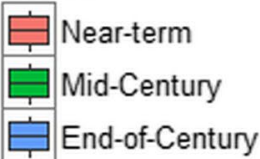

Fig. 3 Projected changes in monthly minimum temperatures for RCP4.5 (left) and RCP8.5 (right) for near term, mid-century and end of century future periods

\section{Projected changes in rainfall}

The monthly percentage changes in rainfall computed from baseline to future climate and per future time period for the two scenarios, RCP4.5 and RCP8.5, is presented in Fig. 4. The erratic nature of rainfall leads to a number of outliers, especially in closer future periods. Acknowledging larger uncertainty in projecting rainfall compared to temperatures, we focus on observing most simulated changes and exclude outliers from our observations and discussion.

Rainfall is expected to increase at all stations, for both $\mathrm{RCPs}$, and the percentage of change increases in time from near-term to end-of-century. The largest projected median change of $+20 \%$ is expected in Hawassa under RCP 8.5 by the end of the century. Both under RCP 4.5 and RCP8.5 an increase in rainfall is consistently projected for Hawassa, meanwhile the rainfall increase is 

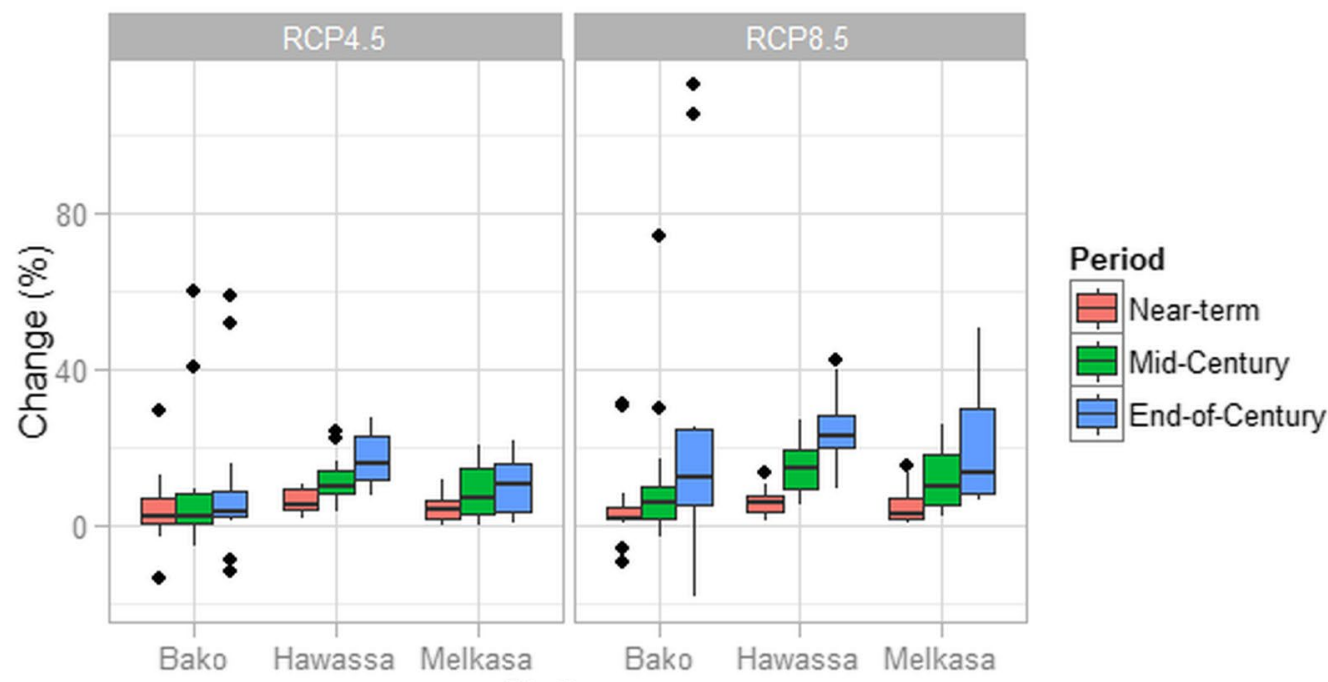

Stations

Fig. 4 Monthly rainfall changes (\% of baseline) for two RCP4.5 (left) and RCP8.5 (right), per station and per future time periods (near term, mid and end of century)

Table 4 Model capacity to represent local systems

\begin{tabular}{|c|c|c|c|c|c|c|c|c|}
\hline Station & Soil & Maize variety & Fertilization & $\begin{array}{l}\text { Average obs. yield } \\
\text { (t/ha) }\end{array}$ & $\begin{array}{l}\text { Average simulated } \\
\text { yield }(\mathrm{t} / \mathrm{ha})\end{array}$ & RMSE & d-stat & $r$ \\
\hline Bako & $\begin{array}{l}\text { Reddish brown } \\
\text { Nitosol }\end{array}$ & Bako Hybrid 540 & $\begin{array}{l}100 \mathrm{~kg} / \mathrm{ha} \text { urea and } \\
100 \mathrm{~kg} / \mathrm{ha} \text { DAP }\end{array}$ & 8.28 & 8.8 & 0.92 & 0.67 & 0.75 \\
\hline Melkassa & Deep grey Fluvisols & Melkassa I & $\begin{array}{c}50 \mathrm{~kg} / \mathrm{ha} \text { urea and } \\
100 \mathrm{~kg} / \mathrm{ha} \mathrm{DAP}\end{array}$ & 2.1 & 2.8 & 0.84 & 0.77 & 0.65 \\
\hline Hawassa & Vitric Andosols & Bako Hybrid 540 & $\begin{array}{c}100 \text { kg/ha urea and } \\
100 \mathrm{~kg} / \mathrm{ha} \text { DAP }\end{array}$ & 5.2 & 6.6 & 0.8 & 0.56 & 0.7 \\
\hline
\end{tabular}

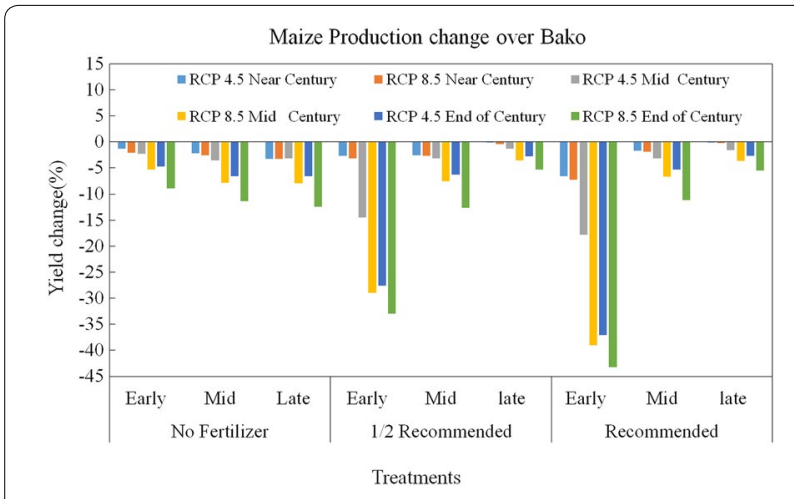

Fig. 5 The Simulated maize yield in relation to future climate scenario at Bako

limited for Bako under RCP4.5 (which shows the largest number of outliers). The results are in agreement with those previously reported in the other parts of the country (e.g., Hadgu et al. 2015; Muluneh et al. 2015; Tesfaye et al. 2014; Kassie et al. 2013). Kassie et al. (2013) found an increase in annual rainfall and the highest was projected to increase by 28 and 38\% for RCP 4.5 and RCP 8.5 , respectively. The study by Muluneh et al. (2015) also reported that the projected main rainy season (Kiremt) rainfall increase up to $32 \%$ in the Central Rift Valley (CRV) of Ethiopia.

\section{Future yield simulations Impact of climate change}

The DSSAT result that shows the maize yield for Bako, Melkassa and Hawassa stations are ranges between 2.8 and $8.8 \mathrm{t} / \mathrm{ha}$ in the baseline scenario, and between 2.1 and $9.9 \mathrm{t} / \mathrm{ha}$ in the climate change scenarios (see Table 4 for baseline, and Figs. 5, 6 and 7 for climate change scenarios). The simulated maize yield for the future climate scenarios indicates that, maize yields are expect to be lower than baseline at Bako and Melkassa, and higher at Hawassa. The percent of yield change were high for all stations (see Figs. 5, 6, 7). The maximum yield change 


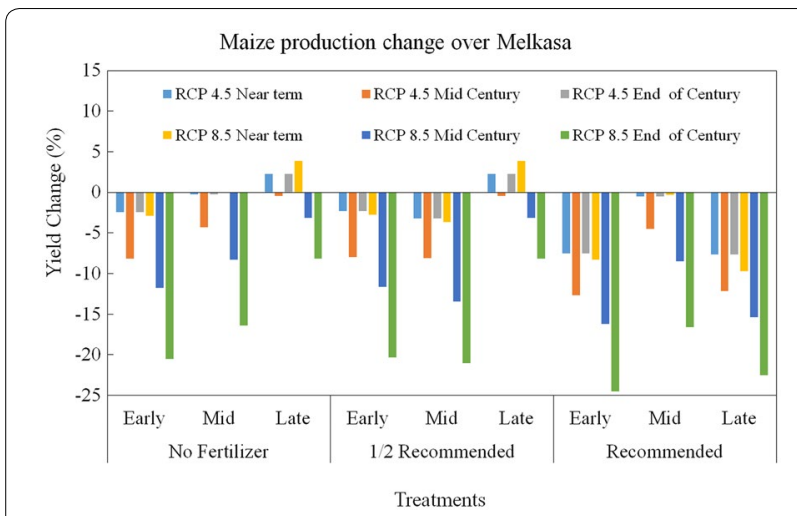

Fig. 6 The simulated maize yield in near term, mid and end of century at Melkassa

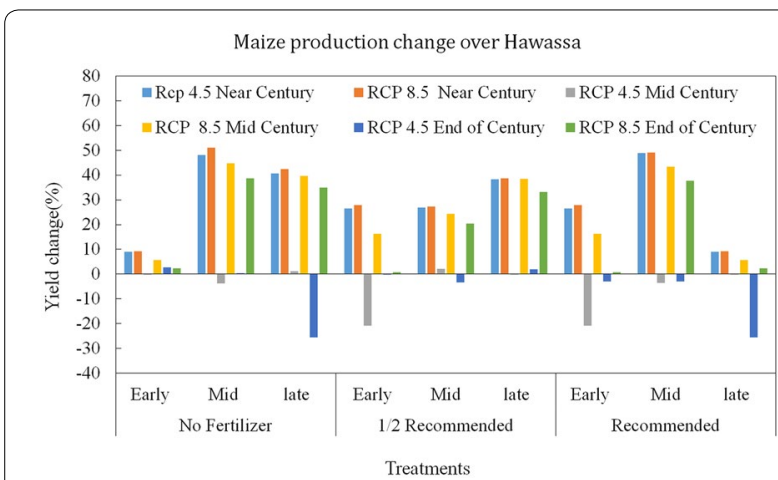

Fig. 7 The simulated maize yield in relation to future climate scenarios at Hawassa

in Bako (- 43.21\%) and Melkassa (-24.5\%) is predicted under RCP8.5, while at Hawassa, the maximum yield changes $(+51 \%)$ was predicted under RCP8.5 during the near century. On the other hand, the minimum yield change for Bako $(-2 \%)$ and Melkassa $(-2 \%)$ was predicted under RCP4.5 during the end of century.

The order of magnitude of the yield change we found is broadly consistent with previous studies (Kassie et al. 2015; Muluneh et al. 2015; Schlenker and Lobell 2010). Inline to this study, Muluneh et al. (2015) found that an increase and decrease of maize yield at two different stations due to projected climate change. Thornton et al. (2009) reported that maize yield can be expected to increase in the central and southern Ethiopian highlands. The observed range of yield decrease concur with Kassie et al. (2015), they indicated maize yield reductions of about $20 \%$ in the Central Rift Valley by 2050 s. The decrease in yield from overall climate change impact was due to increased evapotranspiration (ETO) that results from increased temperatures (Kassie et al. 2015; Muluneh et al. 2015).

\section{Adaptation options}

Bako, a sub humid area In all climate change scenarios, individual adaptation options, changing planting dates and application of fertilizer, decreased maize yield at Bako (Fig. 5). The largest declines (up to $-40 \%$ ) are projected under RCP4.5 (end-of-century) and RCP8.5 (mid-century and end-of-century) exclusively under early planting. The smallest declines (up to $-2 \%$ ) for both RCP4.5 and RCP8.5 are expected under a combination of late planting and half or full recommended fertilizer rates (unlike Melkassa, see next section). Independently of planting, fertilizing or RCPs combinations, maize yields decrease further with time. Without fertilization, planting dates provided little difference in yield reduction, while under half or recommended fertilizer application (i) early planting leads to the largest yields decline and (ii) late planting leads for the smallest yields decline outcomes.

For Bako, the combination of high fertilizer rate with late planting resulted the best response to detrimental effect of future climate on yields. This noticeably differs from Melkassa (presented in the next section) where low fertilization (with late planting as well) appeared to be the best alternative response to future climate.

Melkassa, a semi-arid area The future maize yields simulated at Melkassa show consistent decrease across RCPs (Fig. 6). The largest yield decrease is unanimously simulated under RCP8.5 during the end of century period independently of fertilization or planting date. The rare and limited yield increases (up to $+4 \%$ ) are simulated under RCP4.5 (near term and end-of-century) and RCP8.5 (near term) only in combination with late planting and no or half recommended fertilizer application. While under RCP8.5 yield projections decrease further with time (near term, then mid-century, then end-of century), projections under RCP4.5 decrease further until mid-century and recover by the end-of-century to levels comparable to near-term. Independently of RCPs or time period, results suggest that late planting in combination with no or half recommended fertilization amounts are the best possible combinations, either improving yields under RCP4.5 or limiting the yield decrease under RCP8.5. Recommend fertilization application appeared to be detrimental for early or late planting. While yield changes vary largely in response to the planting date (early, mid- and late), fertilizer rates could have very limited effects.

Hawassa, a sub-moistarea The maize production change over Hawassa is shown in Fig. 7. Unlike both previous stations, maize yield in Hawassa are expected to mostly benefit from future climate. The largest yield increases (up to $+50 \%$ ) are expected in the near-term under both RCP4.5 and RCP8.5, for mid planting period, with no and full fer- 
tilizer rates only. The largest yield decreases (up to $-25 \%$ ) are projected under RCP4.5 either by the end of century in combination with late planting, or by mid-century in combination with early planting. As for Bako, the benefits decline with time under RCP8.5, whereas under RCP4.5 the benefits either (i) severely decline by mid-century before increasing by end-of-century in combination with early planting, or (ii) decline continuously with time with late planting dates.

Starting from comparable yield increases in the near term, the latter leads to RCP8.5 projections unusually offering better outcomes, though reducing with time. It is noticeable that RCP8.5 projections all result in increased yields, while under RCP4.5 projections decline drastically from similar near-term expectations to no increase or decrease in the mid-century and end-of-century. As usual the near term period present the highest (in that case highly beneficial) yield expectations independently of planting, fertilizing or RCPs. However, quite unusually maize yield simulations show higher improvements under RCP8.5 than under RCP4.5. In addition, while RCP8.5 projections remain all beneficial (all increases) despite a decline in time, yield projections under RCP4.5 decline drastically up to $-26 \%$ decrease either (i) as soon as mid-century in combination with early planting, or (ii) end-of-century in combination with late planting.

For Hawassa station, planting date play a major role in combination with RCP/time period to improve the yield in the area. While there is no evident "best" planting decision unlike late planting at both Bako and Melkassa, results suggest "worst" planting decisions under RCP4.5 in combination with future period; (1) late planting and end of century, and (2) early planting and mid-century. Near term overall appeared to be the most fruitful period and strongly suggest potential for improvement under increased temperature and increase rainfall whether under RCP4.5 or RCP8.5.

Adjusting planting dates and application of fertilizer are among the most widely studied strategies of adapting to climate change (Kassie et al. 2015; White et al. 2011). Our analysis indicated that late planting in Bako and Melkassa, and mid-window planting in Hawassa, combination with recommend fertilization application provided highest yield in all stations. In line with our results, Muluneh et al. (2017), Kassie et al. (2015) and Biazin and Sterk (2013) in Ethiopia, reported an increase in maize yields with delayed planting dates and nitrogen application for climate change scenarios. The significant impact of late planting would concur with works from Biazin and Sterk (2013) suggesting to wait for sufficient moisture needed for an efficient seed germination. Similar to our result, Kassie et al. (2015) indicated that increasing nitrogen fertilizer rate by $60 \mathrm{~kg} / \mathrm{ha}$ did yields increase by $78-89 \%$ in across the climate change scenarios in Ethiopia.

\section{Conclusions}

Climate change/variability and its impact, as projected by the 19 GCMs in combination with 2 Representative Concentration Pathways and crop model, demonstrate variable response of maize crop yield in maize growing areas of Ethiopia. From a climate only perspective, the RCP8.5 translating higher atmospheric greenhouse gas concentrations and higher increase in temperatures, shows as expected larger detrimental impact in Bako and in Melkassa, but it also unusually offers the most stable benefit over time in Hawassa. The yield responses over time varies as well, from a constant decrease of performances over time in Bako independently of the RCP, to a decrease in time from near-term to mid-century before increasing back by the end-of-century in Melkassa and Hawassa under RCP4.5.

From a treatment perspective, planting dates and fertilizer rates always have an effect over simulated yield responses, yet the most promising combinations largely vary from one to another location. In Bako, a combination of late planting and medium-to-high fertilization rates respond best to the detrimental effects of future climate. In Melkassa, a combination of late planting and low-to-medium fertilization rates respond best to the detrimental effects of future climate. And in Hawassa, future climate is mostly shown beneficial to simulated future yields, the largest benefit resulting from low-orhigh fertilization rates in combination with mid-window planting dates. Shifting the planting date can reduce the risk of crop failure and offset the predicted yield reduction caused by climate change.

The improved yield responses under future climate in Hawassa could be a direct effect of larger projected increases in monthly rainfall, hence allowing to benefit from higher projected temperatures. Under a comparable increase in monthly temperatures but this time with limited increase in rainfall in Bako and Melkassa, the results support the value of planting later in an attempt to secure adequate moisture in the soil, hence reducing the sensitivity of- and the risk of- prolonged dry spell at early sensitive growth stage.

Considering temperature and rainfall changes, two major determining factors of agricultural production and food security, the results emphasize extremely variable outcomes. On one side, future maize yields are consistently decreasing and, fertilizer and planting treatments variation only offer an opportunity to limit the negative impact of future climate change in Bako and Melkassa. On the other side, future maize yields are consistently increasing and, fertilizer and planting treatments 
variation become a tool to benefit the most from the impact of future climate change in Hawassa. However, the increase in yield with changing planting date and fertilizer application under climate change scenarios is conditional on the use of other measures, such as adjusted irrigation and crop protection, to enable realization of potential yield increases.

Through three major production areas in Ethiopia, this study improves our understanding of local production variations under global climate change. It provides impact assessment in the light of a range of GCMs, a set of treatments and 2 RCPs, allowing for an exploration of adaptation options best suited at locale scale, to feed into larger provincial and national future production schemes. This study further strengthens our understanding of the impact of global climate changes on local agricultural food production systems, and the need of good local knowledge to better address global climate challenges.

\section{Authors' contributions}

KA, JS and FM have made contributions in the acquisition of the data, data collection, data coding and entry, data analysis, interpretation of the result. OC has been involved in critically advising, revising the manuscript and made possible suggestion. All authors read and approved the final manuscript.

\section{Author details}

${ }^{1}$ Climate System Analysis Group, University of Cape Town, Rondebosch, Cape Town 7701, South Africa. ${ }^{2}$ Ethiopian Institute of Agricultural Research, P.O. Box 2003, Addis Ababa, Ethiopia.

\section{Acknowledgements}

The authors are grateful to the Climate Impacts Research Capacity and Leadership Enhancement (CIRCLE), which gave the opportunity to start a 1 year research project and financial support. The authors would like to thank Melkassa Agricultural Research Center, Bako Research Center, Hawassa Research Center and Debrezeit Research Center for providing important inputs for this research. The authors gratefully acknowledge the support made by Samuel Tesfaye, Mezgebu Getnet and Nkulumo Zinyenger.

\section{Competing interests}

The authors declare that they have no competing interests.

\section{Availability of data and materials \\ Not applicable.}

\section{Consent for publication}

Not applicable.

\section{Ethics approval and consent to participate}

Not applicable.

\section{Funding}

The full cost of this study was covered by Climate Impacts Research Capacity and Leadership Enhancement (CIRCLE) project, co-operated by African Academic Science (AAS) and UKAID.

\section{Publisher's Note}

Springer Nature remains neutral with regard to jurisdictional claims in published maps and institutional affiliations.

Received: 22 July 2017 Accepted: 1 February 2018

Published online: 13 February 2018

\section{References}

Admassu S (2004) Rainfall variation and its effect on crop production in Ethiopia. MSc. thesis, Department of Civil Engineering, Addis Ababa University, Ethiopia

AgMIP (2013a) Guide for running AgMIP climate scenario generation tools with $R$ in windows. AgMIP, New York

AgMIP (2013b) The coordinated climate-crop modeling project C3MP: an initiative of the agricultural model intercomparison and improvement project. C3MP protocols and procedures. AgMIP, New York

AgMIP (2013c) Guide for regional integrated assessments: handbook of methods and procedures, version 5. Center for Climate Systems Research, Earth Institute, Columbia University. AgMIP, New York

Alemayehu A, Bewket W (2016) Local climate variability and crop production in the central Highlands of Ethiopia. Environ Dev 19:36-48

Alemu D, Wilfred M, Nigussie M, David JS (2008) The maize seed system in Ethiopia: challenge and opportunities in drought prone areas. Afr J Agric Res 3(4):305-314

Alliance for a Green Revolution in Africa (AGRA) (2014) African agriculture status report; climate change and smallholder agriculture in sub-Saharan Africa. Alliance for a Green Revolution in Africa (AGRA), Nairobi

Andrew W, Robertson J, Amor V, Ines M, James W (2007) Downscaling of seasonal precipitation for crop simulation. J Appl Meteorol Climatol. https:// doi.org/10.1175/JAM.2495.1

Araya A, Girma A, Getachew F (2015) Exploring impacts of climate change on maize yield in two contrasting agro-ecologies of Ethiopia. Asian J Appl Sci Eng 4:27-37

Ayalew D, Tesfaye K, Mamo G, Yitaferu B, Bayu W (2012) Variability of rainfall and its current trend in Amhara region, Ethiopia. Afr J Agric Res 7(10):1475-1486

Bewket W (2009) Rainfall variability and crop production in Ethiopia: case study in the Amhara region. In: Ege S, Aspen H, Teferra B, Bekele S (eds) Proceedings of the 16th international conference of Ethiopian studies, Trondheim, Norway

Bewket W, Conway D (2007) A note on the temporal and spatial variability of rain fall in the drought-prone Amhara region of Ethiopia. Int J Climatol 27:1467-1477

Bhattacharjeea PS, Zaitchik BF (2015) Perspectives on CMIP5 model performance in the Nile River headwaters regions. Int J Climatol 35:4262-4275. https://doi.org/10.1002/joc.4284

Biazin B, Sterk G (2013) Drought vulnerability drives land-use and land cover changes in the Rift Valley dry lands of Ethiopia. Agric Ecosyst Environ 164:100-113. https://doi.org/10.1016/j.agee.2012.09.012

Boko M, Niang I, Nyong A, Vogel C, Githeko A, Medany M, Osman-Elasha B, Tabo R, Yanda P (2007) Africa, in climate change 2007: impacts, adaptation and vulnerability. Cambridge University Press, Cambridge

Brands S, Herrera S, Fernandez J, Gutiérrez JM (2013) How well do CMIP5 Earth System Models simulate present climate conditions in Europe and Africa? A performance comparison for the downscaling community. Clim Dyn 41:803-817. https://doi.org/10.1007/s00382-013-1742-8

Bryan E, Deressa TT, Gbetibouo GA, Ringler C (2009) Adaptation to climate change in Ethiopia and South Africa: options and constraints. Environ Sci Policy 12:413-426

Burney J, Cesano D, Russell J, La Rovere EL, Corral T, Coelho NS, Santos L (2014) Climate change adaptation strategies for smallholder farmers in the Brazilian Sertão. Clim Change 126:45-59

Conway D, Schipper ELF (2011) Adaptation to climate change in Africa: challenges and opportunities identified from Ethiopia. Glob Environ Change 21:227-237

CSA (Central Statistical Agency) (2012) Agricultural sample survey: report on area and production of major crops (private peasant holdings, Meher season). Statistical Bulletin 1, Addis Ababa, Ethiopia

CSA (central statistical authority) (2015) Agricultural sample survey report on area and production for major crops (private peasant holdings Meher season) for 2007/08. The Federal Democratic Republic of Ethiopia. Statistical Bulletin 278, Addis Ababa, Ethiopia

Deressa TT, Hassan RM (2009) Economic impact of climate change on crop production in Ethiopia: evidence from cross-section measures. J Afr Econ 18:529-554

Diaz-Nieto J, Wilby RL (2005) A comparison of statistical downscaling and climate change factor methods: impacts on low flows in the River Thames, United Kingdom. Clim Change 69:245-268 
Erkossa T, Itanna F, Stahr K (2007) Indexing soil quality: a new paradigm in soil science research. Aust J Soil Res 45:129-137

Eshetu Z, Simane B, Tebeje G, Negatu W, Amsalu A, Berhanu A, Bird N, Welham B, Trujillo NC (2014) Climate finance in Ethiopia. Overseas Development Institute, London and Climate Science Centre, Addis Ababa

Food for Agriculture Organization of the United Nations (FAO) (2016) Challenges facing agriculture and food security: situation report. http:// www.fao.org/fileadmin/user_upload/emergencies/docs/FAO\%20Ethiopia_El\%20Nino\%20Situation\%20Report_February\%202016.pdf. Accessed 8 June 2017

Fowler HJ, Blenkinsop S, Tebaldi C (2007) Linking climate change modeling to impacts studies: recent advances in downscaling techniques for hydrological modeling. Rev Int J Climatol 27:1547-1578

Notre Dame-Global Adaptation Index (ND-GAIN) (2016) Summarizes a country's vulnerability to climate change and other global challenges in combination with readiness to improve resilience. https://gain-new.crc. nd.edu/ranking/readiness. Accessed 2 June 2017

Hadgu G, Tesfaye K, Mamo G (2015) Analysis of climate change in northern Ethiopia: implications for agricultural production. Theor Appl Climatol 121(3):733-747. https://doi.org/10.1007/s00704-014-1261-5

Hoogenboom G, Jones JW, Wilkens PW, Porter CH, Hunt LA, Boote KJ, Singh U, Uryasev O, Lizaso JI, White JW, Ogoshi R, Gijsman AJ, Batchelor WD, Tsuji GY (2009) Decision Support System for Agrotechnology Transfer (DSSAT) version 4.5. University of Hawaii, Honolulu

Hoogenboom G, Jones JW, Traore PC, Boote KJ (2012) In the book. In: Kihara J (ed) Improving soil fertility recommendations in Africa using the Decision Support System for Agrotechnology Transfer (DSSAT). Springer Science + Business Media B.V, Dordrecht. https://doi. org/10.1007/978-94-007-2960-52

IPCC (2012) Managing the risks of extreme events and disasters to advance climate change adaptation. In: Field CB, Barros V, Stocker TF, Qin D, Dokken DJ, Ebi KL, Mastrandrea MD, Mach KJ, Plattner GK, Allen SK, Tignor M, Midgley PM (eds) A special report of working groups I and II of the intergovernmental panel on climate change. Cambridge University Press, Cambridge, p 582

Jones PG, Thornton PK (2003) The potential impacts of climate change on maize production in Africa and Latin America in 2055. Glob Environ Change Hum Policy Dimens 13(1):51-59

Jury MR (2015) Statistical evaluation of CMIP5 climate change model simulations for the Ethiopian highlands. Int J Climatol 35:37-44. https://doi. org/10.1002/joc.3960

Jury MR, Funk C (2013) Climatic trends over Ethiopia: regional signals and drivers. Int J Climatol 33:1924-1935

Kassie BT, Rötter RP, Hengsdijk H, Asseng S, Van Ittersum MK, Kahiluto H, Van Keulen H (2013) Climate variability and change in the Central Rift Valley of Ethiopia: challenges for rainfed crop production. J Agric Sci 152:58-74

Kassie BT, Van Ittersum MK, Hengsdijk H, Asseng S, Wolf J, Rotter RP (2014) Climate induced yield variability and yield gap of maize (Zea mays L.) in the Central Rift Valley of Ethiopia. Field Crops Res. https://doi.org/10.1016/j. fcr.2014.02.010

Kassie BT, Asseng S, Rotter RP, Hengsdijk H, Ruane AC, Van Ittersum MK (2015) Exploring climate change impacts and adaptation options for maize production in the Central Rift Valley of Ethiopia using different climate change scenarios and crop models. Clim Change 129(1-2):145-158. https://doi.org/10.1007/s10584-014-1322-x

Kurukulasuriya P, Mendelsohn R, Hassan R, Benhin J, Deressa T, Diop M, Eid HM, Fosu KY, Gbetibouo G, Jain S, Mahamadou A, Mano R, Kabubo-Mariara J, El Marsafawy S, Molua E, Ouda S, Ouedraogo M, Sene I, Maddison D, Seo SN, Dinar A (2006) Will African agriculture survive climate change? World Bank Econ Rev 20:367-388

Lemi A (2005) Rainfall probability and agricultural yield in Ethiopia. East Afr Soc Sci Res Rev 21(1):57-96

Ministry of Agriculture and Rural Development (MOARD) (2009) Animal and plant health regulatory, crop variety register issue no. 12. Ministry of Agriculture and Rural Development (MOARD), Addis Ababa

Mourice SK, Rweyemamu CL, Tumbo SD, Amuri N (2014) Maize cultivar specific parameters for Decision Support System for Agrotechnology Transfer (DSSAT) application in Tanzania. Am J Plant Sci 5:821-833. https://doi. org/10.4236/ajps.2014.56096

Müller C, Cramer W, Hare WL, Lotze-Campen H (2011) Climate change risks for African agriculture. Proc Natl Acad Sci 108:4313-4315
Muluneh A, Birhanu B, Stroosnijder L, Bewket W, Keesstra S (2015) Impact of predicted changes in rainfall and atmospheric carbon dioxide on maize and wheat yields in the Central Rift Valley of Ethiopia. J Reg Environ Change. https://doi.org/10.1007/s10113-014-0685-x

Muluneh A, Stroosnijder L, Keesstra S, Biazin B (2017) Adapting to climate change for food security in the Rift Valley dry lands of Ethiopia: supplemental irrigation, plant density and sowing date. J Agric Sci 155:703-724. https://doi.org/10.1017/S0021859616-000897

NMA (National Meteorological Agency) (2007) Climate change national adaptation programme of action (NAPA) of Ethiopia: technical report. Addis Abeba, National Metorological Agency, p 85

Rosenzweig C, Ruane AC, Winter JM, Boote KJ, Porter C, Jones J, Wasseng S, Hatfield JL, Thorburn P, Antle JM, Nelson GC, Janssen S, Basso B, Ewert F, Wallach D, Baigorria G (2013) The agricultural model intercomparison and improvement project (AgMIP): protocols and pilot studies. J Agric For Meteorol 170:166-182

Schlenker W, Lobell DB (2010) Robust negative impacts of climate change on African agriculture. Environ Res Lett 5:014010

Seleshi Y, Zanke U (2004) Recent changes in rainfall and rainy days in Ethiopia. Int J Climatol 24:973-983. https://doi.org/10.1002/joc.1052

Setegn SG, Rayner D, Melesse AM, Dargahi B, Srinivasan R, Wörman A (2011) Climate change impact on agricultural water resources variability in the Northern Highlands of Ethiopia. In: Melesse AM (ed) Nile River Basin. Springer, Dordrecht, pp 241-265. https://doi. org/10.1007/978-94-007-0689-7_12

Soltani A, Hoogenboom G (2003) Assessing crop management options with crop simulation models based on generatedwhether data. Field Crops Res 103:198-207

Taffesse A, Dorosh P, Asrat S (2011) Crop production in Ethiopia regional patterns and trends. Ethiopia strategy support program II

Taylor KE, Stouffer RJ, Meehl GA (2012) An overview of CMIP5 and the experiment design. Bull Am Meteorol Soc 93:485-498

Tefera A (2012) Ethiopia: grain and feed annual report. Global Agricultural Information Network. USDA Foreign Agriculture Service, report number ET 1201

Tesfaye S, Raj AJ, Gebersamuel G (2014) Assessment of climate change impacts on hydrologic response of Geba Catchment, Tekez Basin, and Northern Ethiopia. Am J Environ Eng 4(2):25-32

Tesfaye S, Birhane E, Leijnse T, van der Zee SEATM (2017) Climatic controls of ecohydrological responses in the highlands of northern Ethiopia. Sci Total Environ 609:77-914. https://doi.org/10.1016/j.scitotenv.2017.07.13

Thornton PK, Jones PG, Alagarswamy G, Andresen J (2009) Spatial variation of crop yield response to climate change in East Africa. Glob Environ Change 19:54-65. https://doi.org/10.1016/j.gloenvcha.2008.08.005

Trzaska S, Schnarr E (2014) A review of downscaling methods for climate change projections. A report made by United States Agency for International Development by Tetra Tech ARD, through a task order under the prosperity, livelihoods, and conserving ecosystems (PLACE) indefinite quantity contract core task order (USAID contract no. AID-EPP1-00-06-00008, order number AID-OAA-TO-11-00064)

United States Department of Agriculture (USDA) (2016) World Agricultural Production. Foreign Agricultural Service. Circular Series WAP 6-16 June 2016. Approved by the World Agricultural Outlook Board

Wheeler T, von Braun J (2013) Climate change impacts on global food security. Science 341:508-513

White JW, Hoogenboom G, Kimball BA, Wall GW (2011) Methodologies for simulating impacts of climate change on crop production. Field Crops Res 12:357-368

Worku M, Twumasi Afriyie S, Wolde L, Tadesse B, Demisie G, Bogale G, Wegary D, Prasanna, B (2012) Meeting the challenges of global climate change and food security through innovative maize research. In: Proceedings of the third national maize workshop, Ethiopia, Addis Ababa

World Bank (2006) Managing water resources to maximise sustainable growth: a country water resources assistance strategy for Ethiopia. World Bank, Washington, DC

World Bank (2010) Economics of adaptation to climate change: Ethiopia. The World Bank Group, Washington, DC, p 124

Yang JM, Yang JY, Liu S, Hoogenboom G (2014) An evaluation of the statistical methods for testing the performance of crop models with observed data. J Agric Syst 127:81-89

Yimer G, Jonoski A, Griensven AV (2009) Hydrological response of a catchment to climate change in the upper Beles river basin, upper blue Nile, Ethiopia. Nile Basin Water Eng Sci Mag 2:49-59 